\title{
Identifikasi Manifestasi Panas bumi Berdasar Interpretasi Citra di Daerah Manokwari, Provinsi Papua Barat
}

\author{
${ }^{1}$ Pribowo A. Kusumo ${ }^{1 *}$ dan Agustinus D. U. Raharjo ${ }^{2}$ \\ ${ }^{1,2}$ Jurusan Teknik Perminyakan, Fakultas Teknik Pertambangan dan Perminyakan \\ Universitas Papua, Papua Barat \\ *Corresponding author, e-mail: p.kusuma@unipa.ac.id
}

\begin{abstract}
Abstrak-, daerah maupun fenomena melalui analisa data yang diperoleh dengan suatu wahana tanpa kontak langsung dengan objek, daerah maupun fenomena tersebut. Dengan demikian untuk fenomena seperti manifestasi panasbumi dapat memanfaatkan kemampaun penginderaan jauh menggunakan satelit yang datanya berupa citra satelit. Penelitian dilakukan di daerah Kebar, Kabupaten Manokwari, Provinsi Papua Barat. Pada penelitian ini citra satelit digunakan untuk menemukan potensi panasbumi baru berupa manifestasi panasbumi di sekitar Distrik Kebar. Data yang digunakan dalam penelitian ini adalah Citra ASTER L1B, Citra SRTM dan Peta RBI. Pengolahan data diawali dengan proses deliniasi, analisa NDVI, analisa pelamparan temperatur permukaan dan proses klasifikasi. Dari hasil pengolahan data ditemukan bahwa terdapat beberapa kemungkinan manifestasi panasbumi baru di Distrik Kebar, Kabupaten Manokwari, Provinsi Papua Barat.
\end{abstract}

Kata Kunci : Citra ASTER, Panasbumi, Distrik Kebar.

\begin{abstract}
Remote sensing is a science or arts to acquired information on object, area, as well as certain phenomenon without direct contact with the object, area or the phenomenon. Thus for geothermal manifestation phenomenon, ones could obtain the data by means of remote sensing using satellite; the data would be satellite image. The study was conducted on area of Kebar District, Manokwari Kabupaten, Papua Barat Province to obtain new possible geothermal manifestation on the area. The data used where ASTER L1B, SRTM image, and RBI map. The data were processed as follow: Delineation evaluation, NDVI Analysis, Surface temperature spreading analysis, and classification. from the data processing, the study found several new geothermal manifestations at Kebar Dsitrict, Manokwari Kabupaten, Papua Barat Province.
\end{abstract}

Keywords : ASTER image, Geothermal, an Kebar District

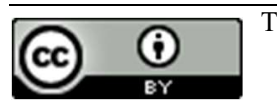

\section{Pendahuluan}

Penginderaan jauh (remote sensing) adalah ilmu dan seni untuk memperoleh informasi tentang suatu objek, daerah atau fenomena melalui analisa data yang diperoleh dengan suatu alat tanpa kontak langsung dengan objek, daerah atau fenomena yang dikaji [11]. Pengambilan data dilakukan dengan memasang sensor pada sebuah platform yang umumnya dapat berupa pesawat terbang, balon, satelit atau wahana lainnya dengan energi tertentu. sedangkan data hasil perekaman dapat berupa Citra (imaginary), grafik, ataupun data numerik.
NASA mengembangkan satelit TERRA dan AQUA sebagai upaya pengumpulan informasi melalui observasi komprehensif secara global [4]. NASA bekerja sama dengan Kementerian Perdagangan dan Industry Jepang mengembangkan sistem sensor yang kemudian dipasang pada Satelit Multimisi Terra. Satelit TERRA dan AQUA memiliki 4 macam sensor, yaitu ASTER (Advance Spacebone Thermal Emission and Reflection Radiometer), MODIS (Moderate Resolution Imaging Spectrometer), CERES dan MISR.

Sensor ASTER memiliki 3 modul subsistem multispektral yang berbeda, masing masing adalah 
VNIR (Visible Near Infrared), SWIR (Shortwave Infrared) dan TIR (Thermal Infrared) dengan resolusi dan panjang gelombang seperti yang dijelaskan pada Tabel 1.

Ketersediaan dan aksesibilitas multispektral data dari satelit menciptakan peluang baru bagi ahli geologi dalam kaitannya dengan pemetaan baik lokal maupun regional.

Citra ASTER memiliki kemiripan dengan citra Landsat didistribusi panjang gelombangnya, perbedaan yang mencolok berada pada saluran TIR dan SWIR. Pada dua saluran ini citra ASTER dipertajam resolusi spektralnya. Berikut perbandingan distribusi gelombang ASTER dan Landsat Gambar 1.

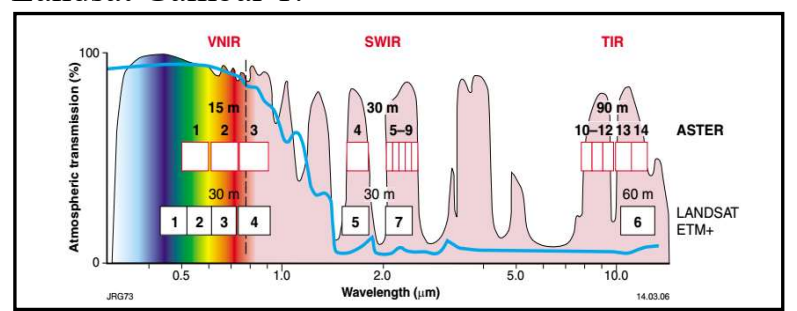

Gambar 1. Perbandingan distribusi gelombang pada ASTER dan Landsat ETM+, [16].

ASTER mampu memetakan beberapa mineral, saluran SWIR mampu mengenali mineral-mineral hasil alterasi hidrothermal seperti; nontronit, pyrophyilite, kaolinit, illit-muskovit-serisit, dan $\mathrm{MgOH}-$ karbonat. Sedangkan TIR mampu mengenali feldspar, kuarsa, karbonat, amphibole, dan tanah liat, namun untuk mengelompokan mineral memerlukan proses yang panjang, dimana efek suhu dan atmosfer harus dihilangkan [7]. Sedangkan TIR dari ASTER yang diambil pada dini hari mampu mendeteksi dengan baik anomali temperatur di permukaan [4] Penelitian

difokuskan di Distrik Kebar, distrik ini masuk dalam wilayah administrasi Kabupaten Manokwari, Provinsi Papua Barat (Gambar 1.)

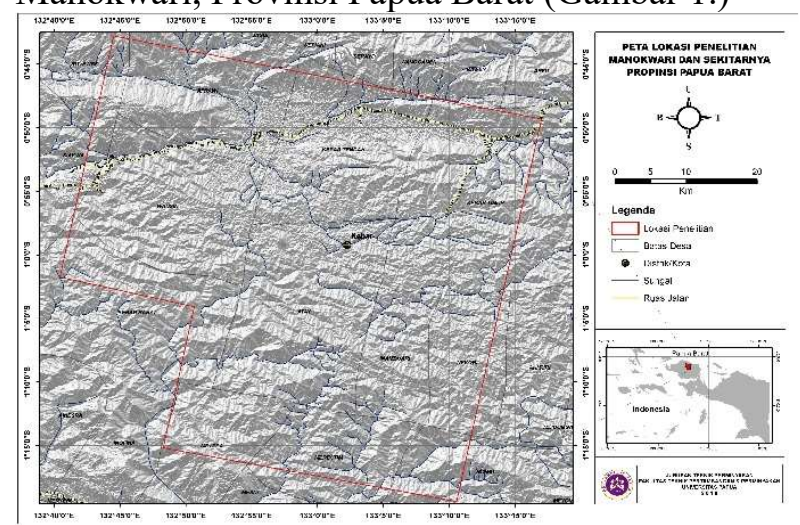

Gambar 1. Lokasi penelitian, Distrik Kebar, Manokwari, Papua Barat.
Provinsi Papua Barat diduga memiliki potensi panasbumi yang cukup besar, namun potensi ini belum dapat teridentifikasi secara maksimal dikarenakan medan yang tidak memungkinkan (akses sulit), tutupan lahan (vegetasi) yang lebat serta sumber daya yang terbatas.

Artikel ioni membahas tentang identifikasi manifestasi-manifestasi panasbumi baru dengan menggunakan alat bantu citra ASTER L1B dan memetakannya dalam bentuk peta terpadu.

\section{METODE}

Terdapat tiga data utama yang digunakan dalam penelitian yaitu: citra SRTM 30 meter, citra ASTER L1B dan peta RBI (Tabel 2.) serta sebuah data pendukung yaitu peta geologi regional, dimana peta ini memberikan informasi gambaran kondisi geologi secara regional.

Geologi Papua dipengaruhi oleh dua lempeng tekonik yang saling bertumbukan secara aktif pada zaman kenozoikum. Adanya aktifitas tektonik miosen menyebabkan terjadinya orogenesa melanesia dan membentuk Fisiografi Papua [6] dengan unit fisiografi terbagi atas tiga satuan geomorfologi (Gambar 2.) antara lain; zona selatan, tersusun atas pegunungan, zona timur Laut tersusun atas bentang alam berbukit dan zona aluvial yang lebar dan luas, zona ini memisahkan zona selatan dan zona timur laut.

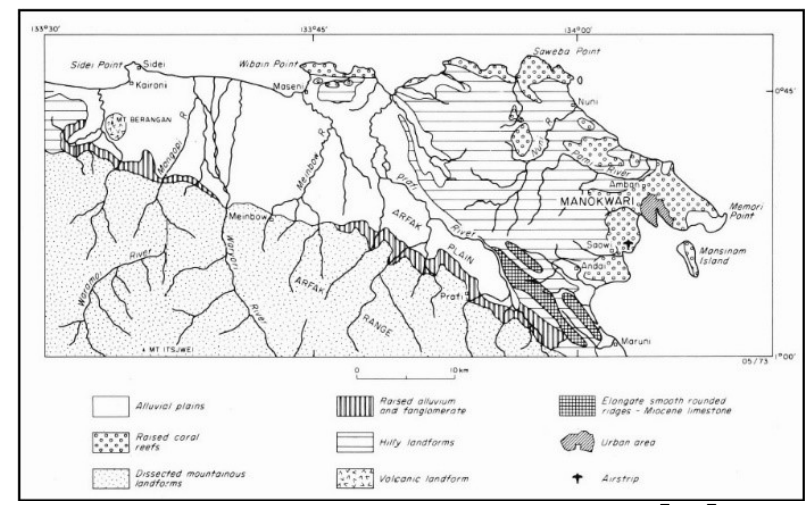

Gambar 2. Fisiografi kepala burung, [13].

Tumbukan lempeng kala eosen membentuk suatu tatanan struktur geologi yang komplek di Papua Barat, kususnya di Kepala Burung [12]. Daerah Kepala Burung menalami kompresi sejak oligosen hingga sekarang membentuk elemenelemen struktur utama antara lain (Gambar 3.): sesar Sorong, blok Kemun-Plateu Ayamaru di baguan utara, sesar Ransiki, jalur lipatan - anjakan Lengguru, cekungan Bintuni dan Salawati di bagian timur, sesar Tarera -Aiduna, antiklin 
Misool-Onin Kumawa dan cekungan Berau di selatan dan barat daya.

Secara geologi, Manokwari telah teridentifikasi beberapa unit satuan (Gambar 4.), dimulai dari zaman silurian - holosen [14], antara lain; formasi kemum tersingkap di wilayah pegunungan selatan, pada formasi ini dijumpai intrusi dan berasimilasi dengan diorit dan gabro yang terdiri dari granitiorit Wariki (akhir permian - trias tengah) dan diorit Lembai (miosen tengah). Intrusi ini mengindikasikan adanya aktifitas magmatisme dimasa silam. Aktifitas magmatisme juga dijumpai di bagian tenggara, pada lokasi ini tersingkap aliran basalt dan andesit, tufa dan sedimen vulkaniklastik, singkapan ini berada di pegunungan Arfak, dengan kiasaran umur oligosen - miosen.

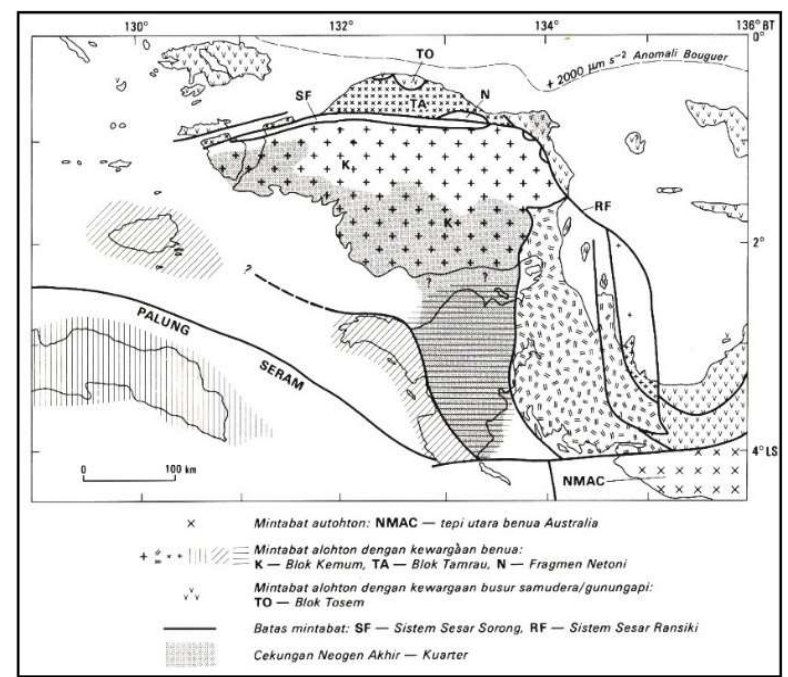

Gambar 3. Tektonostratigrafi kepala burung, [13].

Pada volkanik Arfak dijumpai singkapan yang menjelaskan terdapat perlapisan di bawah formasi Imskin (eosen atas - miosen tengah) berupa limestone fine-grained, [13].

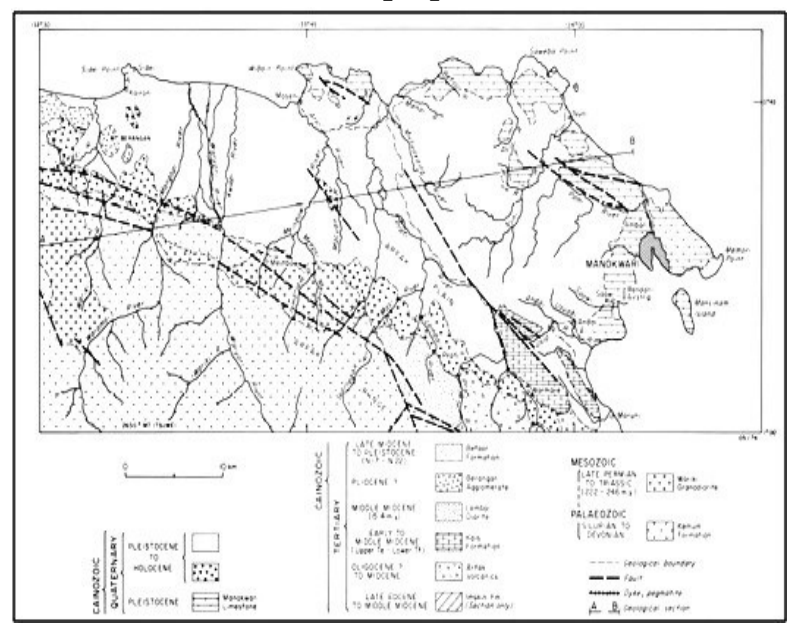

Gambar 4. Geologi manokwari.
Dibagian timur laut kawasan ini (akhir miosen pleistosen) dijumpai soft mudstone, soft siltstone dan soft sandstone (formasi Befoor), pada kala ini terjadi ketidak selarasan dengan kemunculan reefs (Manokwari limestone). Bagian barat terdapat dataran aluvial yang luas, dan terdapat gunung berkomposisi aglomerat yang berumur pliosen (gunung Berangan) dan di sebelah selatan terdapat zona yang terangkat, terbelah, dengan endapan sedimen aluvial kasar dan kanglomerat kasar.

SRTM 30m adalah model elevasi global mirip dengan DEM (digital elevation model) yang terdiri dari kombinasi data shuttle radar topography mission dengan resolusi horizontal $30 \mathrm{~m}$, dan resolusi vertical $\pm 16 \mathrm{~m}$, keunggulan citra SRTM $30 \mathrm{~m}$ selain pada resolusi spasial berada pada kemampuan menembus vegetasi, sehingga gambaran morfologi mendekati yang sebenarnya.

Data citra SRTM 30m untuk kepentingan analisa prediksi struktur geologi tidak dapat langsung digunakan, data ini harus dilakukan pengolahan awal (pre-processing), (Gambar 5).

Data citra SRTM 30m untuk kepentingan analisa prediksi struktur geologi tidak dapat langsung digunakan, data ini harus dilakukan pengolahan awal (pre-processing), (Gambar 5).

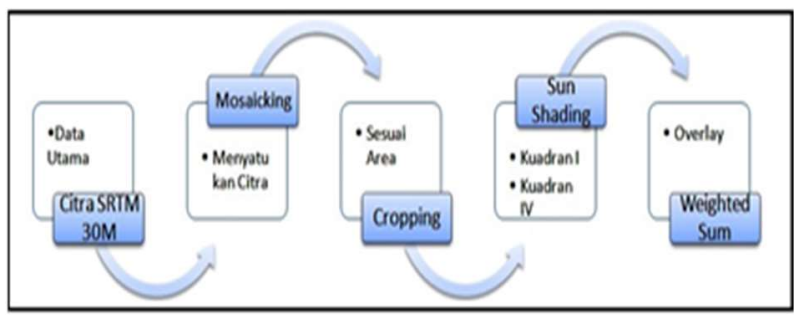

Gambar 5. Pra pengolahan data citra SRTM 30meter

Untuk analisa anomali panas permukaan (anomaly surface temperature) secara ideal data yang digunakan adalah citra ASTER yang diambil dini hari, namun data perekaman malam untuk wilayah Papua dan Papua Barat tidak tersedia, sehingga peneliti menggunakan citra ASTER perekaman siang. Data ASTER level 1B sebelum diolah perlu dilakukan pemrosesan awal yang dikenal dengan preprocessing. Ada beberapa kegiatan preprocessing yang perlu dilakukan sesuwai dengan kondisi data Citra [7], antara lain:

\section{$>$ Orbital parameter correction}

Proses ini diperlukan untuk memperbaiki parameter orbital, dimana Citra yang masih 
mengacu kepada orientasi satelit (swath orientation) diatur agar sesuai dengan permukaan bumi. Citra yang telah dirotasi akan menggunakan proyeksi UTM dengan datum WGS 1984

\section{$>$ Layer stacking}

Layer stacking bertujuan untuk membuat file multi saluran baru dari saluran VNIR, SWIR dan TIR yang telah terkoreksi dengan resolusi yang sama.

\section{$>$ Mosaicking}

Citra ASTER memiliki luas perekaman 60 x $60 \mathrm{~km}$, jika lokasi penelitian mencakup zona yang luas, atau berada diantara batas dua (2) atau 4 (empat) Citra, maka beberapa Citra perlu disatukan menjadi satu kesatuan yang utuh yang idealnya memiliki resolusi temporal yang sama

\section{$>$ Cropping}

Cropping adalah kegiatan memotong Citra yang bertujuan untuk mempertajam analisa sesuai dengan daerah yang diamati.

\section{$>$ Radiance calibration}

Radiance calibration adalah proses memaksimalkan rentang dinamik data dan membuat skala ulang (rescale) nilai brightness agar diperoleh nilai pancaran radiasi atmosfer tertinggi dari nilai digital data mentah (raw) ASTER level 1B. Skala ulang sinyal sensor dilakukan untuk mengubah nilai pixel citra yang semula berupa digital number (DN) akan disesuaikan dalam nilai panjang gelombang masing-masing sensor, (Tabel 3).

Radiance calibration dilakukan dengan menggunakan persamaan matematis [2], seperti yang ditunjukan pada Persamaan 1.

$$
L_{\lambda}=\left(\frac{L M A X_{\lambda}-L M I N_{\lambda}}{Q_{\text {calmax }}-Q_{\text {calmin }}}\right)\left(Q_{\text {cal }}-Q_{Q c a l \text { min }}\right)+L M I N \lambda
$$

dimana: $L \lambda$ adalah spektral radian $(W /(m 2 s r$ $\mu m))$, Qcal adalah rentang nilai pixel $(D N)$, Qcalmin adalah nilai minimun pixel (DN), Qcalmax adalah nilai pixel maksimum (DN), $L M I N \lambda$ adalah nilai spektral minimum sensor $(W /(m 2 s r \quad \mu m)), \quad L M A X \lambda$ nilai spektral maksimum sensor $(W /(m 2 s r \mu m))$.

$>$ Cloud masking

Awan dan bayangan dapat menjadi masalah besar dalam interpretasi citra, masalah yang dimaksud antara lain mengaburkan kondisi permukaan bumi, dan efek dari terang - gelap sebagai respon albedo menghasilkan anomali yang salah dalam pengolahan citra, Untuk itulah masking awan dan bayangannya perlu dilakukan.

Interpretasi struktur geologi berdsar citra dilakukan dengan pendekatan kenampakan morfologi, kriteria morfologi yang menunjukan keberadaan struktur geologi [9], [1], antara lain ;

$>$ Beda tinggi yang mencolok pada area yang sempit

$>$ Pembelokan pola aliran yang mencolok

$>$ Adanya batas yang tegas, dan curam antara perbukitan dan dataran rendah

$>$ Pola kelurusan punggungan.

$>$ Kelurusan gawir.

$>$ Kenampakan dataran yang sempit dan memanjang

$>$ Adanya pola penyebaran tanaman

Transformasi NDVI adalah salah satu metode untuk memetakan kerapatan vegetasi, teknik transformasi ini merupakan penggabungan dari teknik penisbahan dan teknik pengurangan dengan memanfaatkan saluran 2 (band 2) dan saluran 3 (band 3) dari citra ASTER L1B, (Table 3), [7], yang secara matematis dapat dituliskan sebagai berikut :

$$
\begin{aligned}
N D V I= & \left(\frac{B V_{\text {Inframerahdekat }}-B V_{\text {Merah }}}{B V_{\text {Inframerahdekat }}+B V_{\text {merah }}}\right) \ldots . . \\
& \text { dimana: BV adalah band visible }
\end{aligned}
$$

Untuk analisa thermal, hasil prapengolahan Citra ASTER yang sudah dilakukan dilanjutkan dengan tahap pengolahan lanjut, antara lain :

1. Konversi DN ke spectral radiance, (Persamaan 3)

2. Konversi spectral radiance ke $\mathrm{T}\left({ }^{\circ} \mathrm{K}\right)$, (Persamaan 4)

3. Konversi dari nilai $\mathrm{T}\left({ }^{\circ} \mathrm{K}\right)$ menjadi $\mathrm{T}\left({ }^{\circ} \mathrm{C}\right)$, (Persamaan 5)

Konversi DN ke spectral radiance

$L_{R A d}=\left(D N_{j}-1\right) \times U C C$

Konfersi spectral radiance ke $\mathrm{T}\left({ }^{\circ} \mathrm{K}\right)$ 


$$
T=\frac{K_{2}}{\ln \left(\frac{K_{1}}{L_{\lambda}}+1\right)}\left({ }^{\circ} \mathrm{K}\right)
$$

Konfersi spectral radiance ke $\mathrm{T}\left({ }^{\circ} \mathrm{K}\right)$

$$
T=T_{\left({ }^{\circ} \mathrm{K}\right)}-272,5\left({ }^{\circ} \mathrm{C}\right)
$$

Danoedoro [4], menjelaskan bahwa dari pola histogram kita dapat menentukan populasi utama dengan cara pengklasifikasian. Klasifikasi bertujuan untuk memudahkan pembacaan dari data set citra akibat keterbatasan kemampuan mata dalam membuat batasan suatu objek data set citra dengan gradasi warna yang halus.

\section{HASIL DAN PEMBAHASAN}

Analisa prediksi struktur geologi dilakukan secara manual dengan memperhatikan kriteriakriteria struktur geologi berdasar penampakan morfologi, analisa ini dilakukan dengan menarik garis-garis yang memenuhi kriteria sebagai struktur geologi dengan secara manual (on screen), hasil analisa dapat dilihat pada Gambar 6.

Saluran 2 (band 2) memiliki kisaran panjang gelombang $0.63-0.69 \mu \mathrm{m}$, sedangkan saluran 3 (band 3) memiliki kisaran panjang gelombang $0.76-0.86 \mu \mathrm{m}$. Menurut Soetoto \& Setianto, [14]., rentang panjang gelombang $0,63-0,69 \mu \mathrm{m}$ berguna untuk membedakan jenis vegetasi dikarenakan saluran ini terletak pada salah satu daerah penyerapan klorofil, sedang rentang panjang gelombang $0,76-0,90$ $\mu \mathrm{m}$ peka terhadap biomassa vegetasi, unggul dalam identifikasi jenis tanaman dan dapat membedakan tanah dan tanaman serta lahan dan air. Hasil transformasi NDVI menghasilkan Citra dalam grayscale dengan statistik seperti pada Tabel 5.

Untuk memudahkan dalam pengamatan, Citra NDVI diklasifikasikan menjadi beberapa kelompok, teknik klasifikasi menggunakan klasifikasi terbimbing berdasar histogram dari Citra NDVI (Gambar 7.).

Hasil klasifikasi Citra NDVI terlihat pada Gambar 8. dalam Gambar 8 terdapat lima (5) klasifikasi, yaitu daerah dengan vegetasi lebat, sedang, jarang dan terbuka (tanpa vegetasi) serta no data (daerah yang di masking akibat tertutup awan).

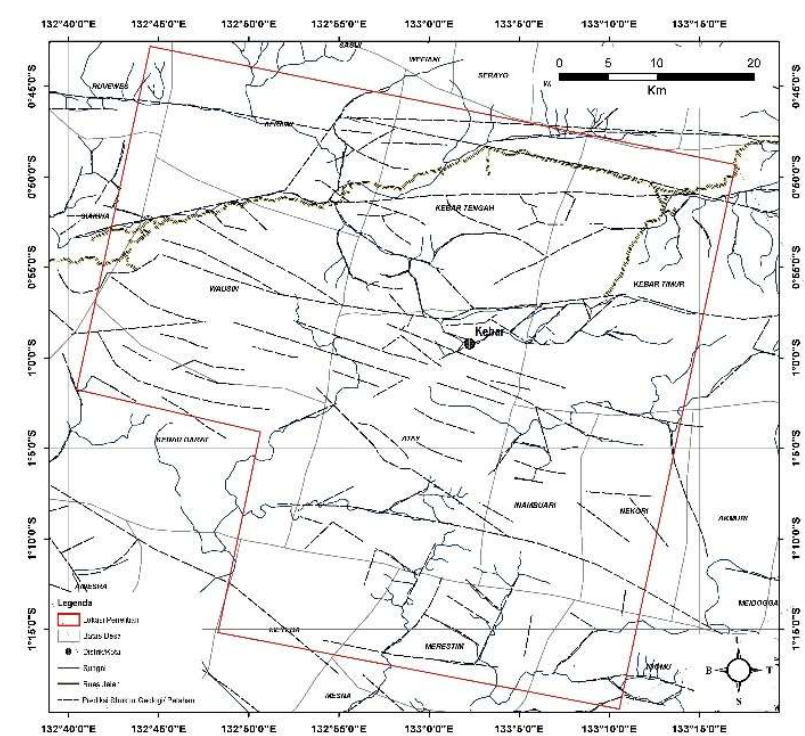

Gambar 6. Peta prediksi struktur geologi dan kelurusannya

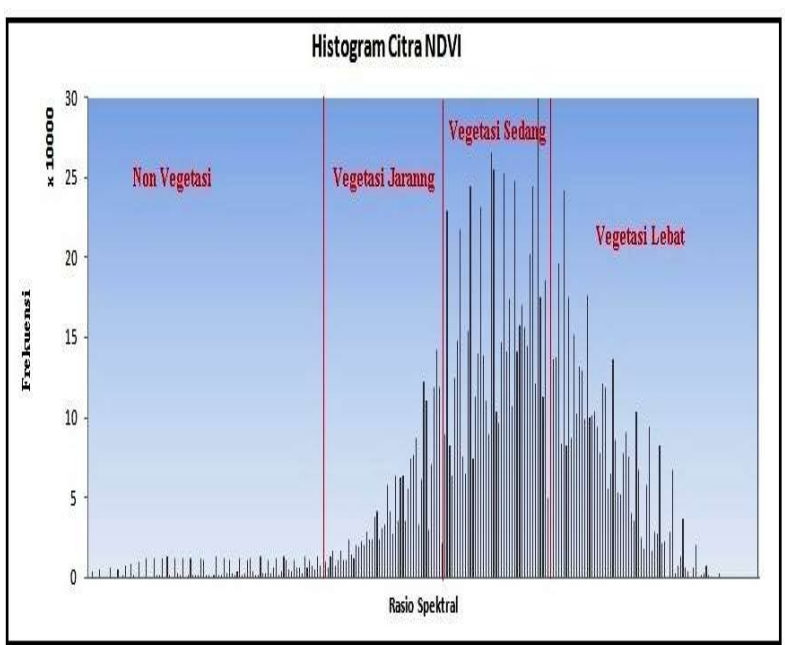

Gambar 7. Histogram citra NDVI

Pada analisa ini peneliti menggunakan TIR saluran 14 (band 14), citra TIR saluran (band) 14 memiliki panjang gelombang 10.95- $11.65 \mu \mathrm{m}$. Menurut Soetoto \& Setianto, [14], kisaran panjang gelombang $10,40-12,50 \pi \mathrm{m}$ memiliki keunggulan dalam pemetaan thermal, membedakan kelembaman tanah, analisa gangguan vegetasi, dan klasifikasi vegetasi.

Citra TIR saluran 14 (band 14) sebelum dianalisa, terlebih dahulu dikonversi dari nilai DN ke spectral radiance (Persamaan 3.), dilanjutkan mengubah nilai spectral radiance menjadi suhu $\left({ }^{\circ} \mathrm{K}\right)$, (Persamaan 4.) dan tahap akhir mengkonversi nilai suhu $\left({ }^{\circ} \mathrm{K}\right)$ menjadi nilai suhu $\left({ }^{\circ} \mathrm{C}\right)$.

Eneva, [6]., menjelaskan ada hubungan antara temperatur dengan perubahan ketinggian (elevation), dimana suhu 
permukaan akan mengalami penurunan seiring dengan bertambahnya elevasi berkisar -9.5 ${ }^{\circ} \mathrm{C} / \mathrm{km}$ (literature meteorology), [6].

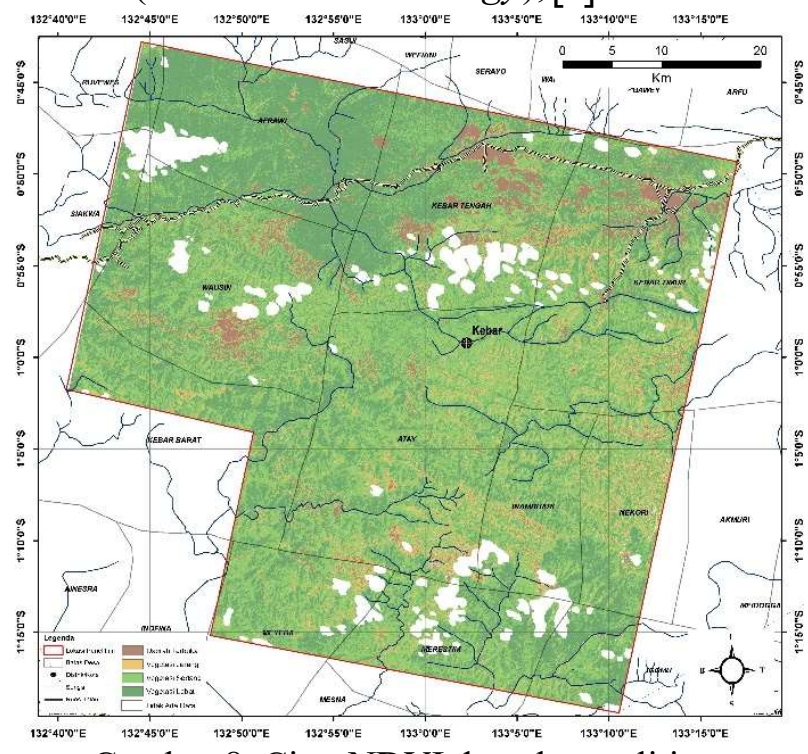

Gambar 8. Citra NDVI daerah penelitian

Menurut penelitian yang dilakukan Eneva[6], di Lapangan Panasbumi Coso, dengan beberapa data citra ASTER malam, pada lokasi yang sama terjadi perbedaan temperatur permukaan dengan nilai beraneka ragam dengan kisaran $-5.4^{\circ} \mathrm{C} / \mathrm{km}$ hingga $-9.8^{\circ} \mathrm{C} / \mathrm{km}$ sebagai efek dari perbedaan ketinggian.

Berdasar kejadian diatas maka nilai piksel yang dikonversi kedalam suhu pada ketinggian yang berbeda akan memiliki nilai yang berbeda, ini dikarenakan nilai piksel dipengaruhi suhu permukaan, sedang suhu permukaan dipengaruhi oleh ketinggian dan musim.

Berdasara kajian di atas, maka dalam mendeteksi spot termal peneliti tidak menggunaka nilai piksel, melainkan menggunakan pendekatan pola dan atau bentuk. Pada umumnya thermal yang berasosiasi dengan aktivitas panasbumi akan muncul pada satu atau beberapa titik dan menyebar secara radial membentuk suatu pola tertutup. Untuk memudahkan pembacaan dalam pendeteksian spot thermal, maka peneliti menggunakan pendekatan klasifikasi. Klasifikasi pada penelitian ini didasarkan pada histogram Citra ASTER TIR saluran 14 (band 14), (Gambar 9.) dan hasil klasifikasi terlihat pada Gambar 10.

Suhu adalah salah satu faktor pertumbuhan tanaman. Suhu permukaan akan menentukan apakah tanah itu akan mendukung terbentuknya hutan lebat, padang rumput, atau dataran yang tandus. Daerah dengan vegetasi yang padat (hutan tropis), suhu permukaan tanah tidak melebihi $35^{\circ} \mathrm{C}$, [19].

Variasi suhu permukaan di zona hutan tropis tidak terlalu tinggi, pada musim panas maupun dingin memiliki rentang variasi suhu rata-rata harian sebesar $3-4,5^{\circ} \mathrm{C}$, pada bulan terpanas suhu permukan berkisar $31-33{ }^{\circ} \mathrm{C}$, dan dibulan terdingin adalah $19-21^{\circ} \mathrm{C},[8]$.

Tanaman tropis pada umumnya memiliki kisaran temperatur tertentu agar tetap dapat melakukan respirasi. Respirasi akan terhenti pada suhu $0^{\circ} \mathrm{C}$, dan respirasi optimum terjadi pada rentang suhu $30-40^{\circ} \mathrm{C},[17]$, sehingga untuk zona dengan temperatur diatas $40^{\circ} \mathrm{C}$ (diatas optimum) akan merusak tanaman, dimana arus respirasi dan absorpsi air pada tanaman akan terganggu dan terhenti.

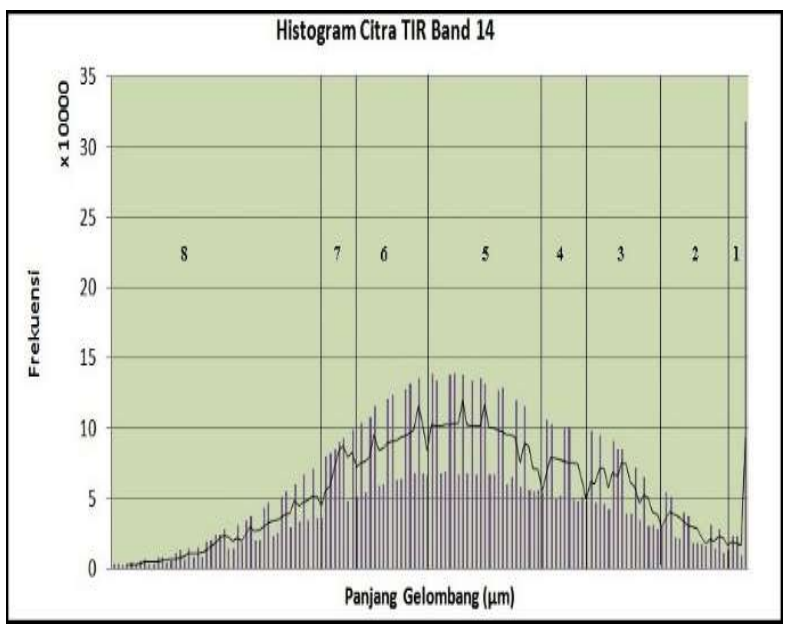

Gambar 9. Histogram citra TIR band 14

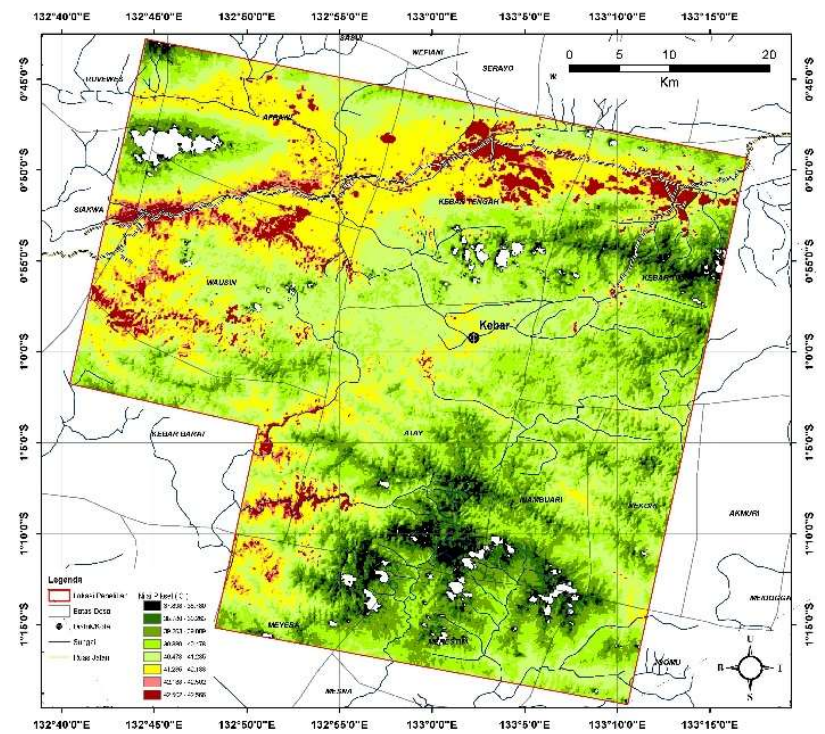

Gambar 10. Klasifikasi citra TIR saluran 14 di daerah penelitian 
Zona panasbumi memiliki temperatur permukaan lebih tinggi daripada temperatur ratarata harian zona tanpa ada aktifitas panasbumi, faktor temperatur yang tinggi ini salah satu indikasi kemunculan aktifitas hydrothermal, faktor temperatur ini juga menentukan lebat tidaknya vegetasi yang ada.

Untuk memastikan apakah spot termal yang tertangkap citra benar-benar anomali termal yang ada kaitannya dengan aktivitas hydrothermal, peneliti mempertimbangkan beberapa aspek (Gambar 11.).

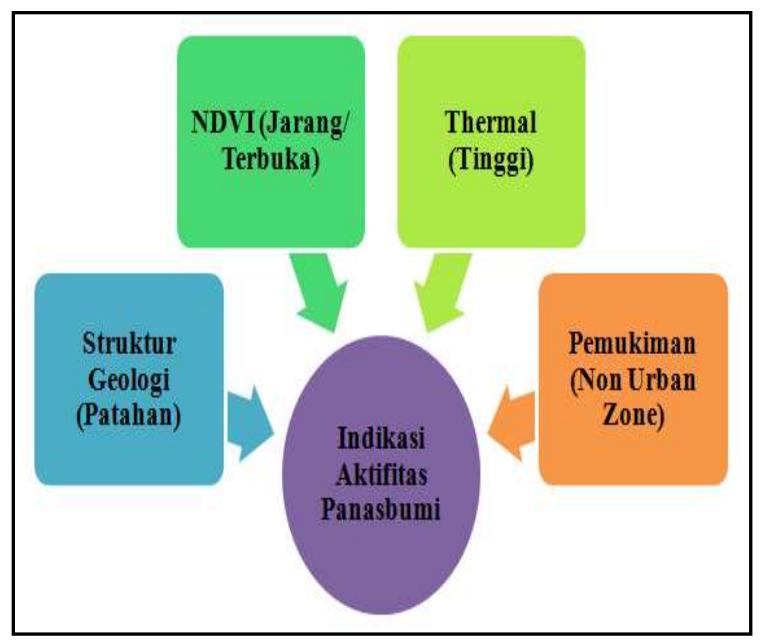

Gambar 11. Metode pendekatan

Spot termal yang dicari adalah spot thermal yang keberadaannya tidak berada di daerah pemukiman, berada atau berdekatan dengan struktur geologi, dan tidak dalam vegetasi yang lebat.

Teknik interpretasi yang digunakan adalah dengan meng-overlaykan semua peta dalam sebuah peta diatas peta morfologi daerah penelitian, sehingga akan memberikan gambaran dan dapat ditarik kesimpulan terkait zona yang dicurigai. Sebagai kalibrasi keakuratan dalam pengolahan citra, digunakan data ordinat lapangan manifestasi panasbumi hasil penelitian peneliti terdahulu (Tabel 6. dan Gambar 12).

Dengan teknik overlay dan hasil validasi data ordinat lapangan manifestasi panasbumi, terdapat 5 zona yang pantas dicurigai sebagai zona yang memiliki kemungkinan akan didapatkan manifestasi panas bumi baru (Lampiran 1).

\section{KESIMPULAN}

Daerah yang memungkinkan terdapat aktifitas panasbumi berdasar analisa citra adalah daerah yang memiliki panas permukaan tinggi, tidak berada pada vegetasi lebat, dilalui atau dekat dengan struktur utama dan tidak berada didaerah pemukiman. Daerah ini dikelompokan menjadi 5 zona yang tersebar di beberapa Distrik, antara lain : Distrik Kebar Tengah ,Distrik Kebar Timur, Distrik Kebar Barat, Distrik Wausin, Distrik Afrawi, Distrik Siakwa.

\section{DAFTAR PUSTAKa}

[1] Burbank. D.W dan Anderson. R. S, Tectonic Geomorphology, 350 Main Street, Malden, MA02148-5020, USA, Blackwell Publishing, 2001.

[2] Chander Gyanesh, Markham Brian L., Helder Dennis L., 200, "Summary of current radiometric calibration coefficients for Landsat MSS, TM, ETM+, and EO-1 ALI sensors" Jurnal Remote Sensing of Environmen, 113, 893-903, 2009.

[3] Chirico. P. G, "An Evaluation Of SRTM, ASTER, And Contour-Based DEMS In The Caribbean Region”, Final Report, Reston VA, 20192, USGS, 2004.

[4] Danoedoro, P., "Pengantar Penginderaan Jauh Digital", Yogyakarta, C.V Andi Offse, 2012.

[5] Departemen Energi \& Sumber Daya Mineral, "Survei Pendahuluan Panas Bumi Manokwari (Ransiki) Provinsi Papua Barat", Laporan Akhir, Bandung, 2009.

[6] Eneva, M," Geothermal Exploration In Eastern California Using Aster Thermal Infrared Data" Final Project Report, California Energy Commission, 2010.

[7] Gozzard, J.R, 2006, "Image Processing of ASTER Multispectral Data" Geological Survey of Western Australia, Western Australia, 2006.

[8] Hall, J. B dan Swaine, M. D., 1981, "Distribution and Ecology of Vascular Plants in a Tropical Rain forest Forest Vegetation in Ghana" Netherlands, Springer Science Business Media, 1981.

[9] Huggett R. Jhon, "Fundamentals of Geomorphology" New York, Routledge Taylor \& Francis Group, 2011.

[10] Lillesand, T. M., dan Kiefer, R. W, "Remote Sensing and Image Interpretation", New York, John Wiley and Sons, 1979.

[11] Meer, F. D. van der, Werff, H. M. A. van der, Ruitenbeek, F. J. A. van, Hecker, C. A., Smeth J. B. de, dan Woldai, T., "Multi- and Hyperspectral Geologic Remote Sensing: A review", International Journal of Applied Earth Observation and Geoinformation 14, (2012), 112-128, 2012.

[12] Pieters. P. E, Hartono. U, dan Amri. C, 1989,"Geologi Lembar MAR, Irian Jaya", 
Bandung, Pusat Penelitian dan Pengembangan Geologi, 1989.

[13] Robinson. G. P dan Ratman Nana," The Stratigraphic and Tectonic Development of Manokwari Area, Irian Jaya", BMR Jurnal of Australian Geology and Geophysics, 3, 19-24, 1978.

[14] Soetoto \& Setianto, A.," Geologi Citra Penginderaan Jauh", Jurusan Teknik Geologi, Fakultas Teknik, Universitas Gadjah Mada, Yogyakarta, 2005

[15] Tsu, H., 1996, "Algorithm Theoretical Basic Document for ASTER Level-1 Data Processing (Ver.3.0)", Earth Remote Sensing Data Analysis Center (ERSDAS), Japan, 1996.

\section{Internet}

[16] http://asterweb.jpl.nasa.gov/images/spectrum.jpg> , diakses 14 Agustus 2018, 12.17 AM.

[17] http://birohmah.unila.ac.id/ pengaruh-suhu maksimum- terhadap-pertumbuhantanaman/\#sthash. uzFIleB. dpuf, diakses 26 September 2018, 09.16 PM.

[18] https://earthdata.nasa.gov/data, diakses tanggal 20 Juni 2017, 04.46 PM.

[19] http://earthobservatory.nasa.gov/GlobalMaps/vie w.php?d1=MOD13A2_M_NDVI\&d2=MOD11C 1_M_LSTDA, diakses tanggal 20 Juni 2017, 04.32 PM.

\section{Biodata Penulis}

Pribowo Angling Kusumo, lahir di Yogyakarta 09 Agustus 1982, Mendapat gelar Sarjana Teknik Perminyakan dengan minat studi teknik panasbumi di Jurusan Teknik Perminyakan, Fakultas Teknologi Mineral, Universitas Pembangunan Nasional "Veteran" Yogyakarta, pada Tahun 2006. Memperoleh gelar Master of Engineering di Program Pascasarjana dengan minat studi teknik panasbumi, Jurusan Teknik Geologi, Fakultas Teknik, Universitas Gadjah Mada pada Tahun 2017. Sejak tahun 2007 Bekerja sebagai tenaga pendidik pada Jurusan Teknik Perminyakan, Fakultas Teknik Pertambangan dan Perminyakan, Universitas Papua.

Agustinus Denny Unggul Raharjo, lahir di Semarang 28 Mei 1977. Memperoleh gelar Sarjana Teknik Perminyakan pada tahun 2005 di Jurusan Teknik Perminyakan Fakutas Teknologi Mineral Universitas Pembangunan Nasional "Veteran" Yogyakarta. Pada tahun 2012 memperoleh gelar Master of Oil and Gas Engineering (MOGE) dari Department of Petroleum Engineering, The
University of Western Australia (UWA) di Perth, Australia. Sejak 2006 bekerja sebagai tenaga pendidik pada Jurusan Teknik Perminyakan, Fakultas Teknik Pertambangan dan Perminyakan, Universitas Papua. 
Tabel 1. Karakteristik sensor ASTER pada satelit Terra, [7].

\begin{tabular}{llc}
\hline Band number & Wavelength $(\mu \mathrm{m})$ & Resolution $(\mathrm{m})$ \\
\hline Band 1 & $0.52-0.60($ visible green) & 15 \\
Band 2 & $0.63-0.69($ visible red) & 15 \\
Band 3 & $0.76-0.86($ nier infrared) & 15 \\
Band 4 & $1.600-1.700$ (shortwave infrared) & 30 \\
Band 5 & $2.145-2.185$ (shortwave infrared) & 30 \\
Band 6 & $2.185-2.225$ (shortwave infrared) & 30 \\
Band 7 & $2.235-2.285$ (shortwave infrared) & 30 \\
Band 8 & $2.295-2.365$ (shortwave infrared) & 30 \\
Band 9 & $2.360-2.430$ (shortwave infrared) & 30 \\
Band 10 & $8.125-8.475$ (thermal infrared) & 90 \\
Band 11 & $8.475-8.825$ (thermal infrared) & 90 \\
Band 12 & $8.925-9.275$ (thermal infrared) & 90 \\
Band 13 & $10.25-10.95$ (thermal infrared) & 90 \\
Band 14 & $10.95-11.65$ (thermal infrared) & 90 \\
\hline
\end{tabular}

Tabel 2. Data penelitian

\begin{tabular}{llll}
\hline No & \multicolumn{1}{c}{ Data } & \multicolumn{1}{c}{ Sumber } & \multicolumn{1}{c}{ Resolusi/ Skala } \\
\hline $\mathbf{1}$ & Citra SRTM & https://earthdata.nasa.gov/data, [18] & 30 meter \\
& & & VNIR : 15 meter \\
$\mathbf{2}$ & Citra ASTER L1B & https://earthdata.nasa.gov/data, [18] & SWIR :30 meter \\
& & & TIR : 90 meter \\
$\mathbf{3}$ & Peta geologi & Lab. Teknik Geologi & $1: 250.000$ \\
$\mathbf{4}$ & Peta RBI (Shp) & UPT Geospasial, Unipa & $1: 50.000$ \\
\hline
\end{tabular}

Tabel 3. Karakteristik sensor ASTER pada satelit Terra, [11].

\begin{tabular}{llll}
\hline Characteristic & VNIR & SWIR & TIR \\
\hline Spectral range & $1: 0.52-0.6 \mu \mathrm{m}$ Nadir Looking & $4: 1.600-1.700 \mu \mathrm{m}$ & $10: 8.125-8.475 \mu \mathrm{m}$ \\
& $2: 0.63-0.69 \mu \mathrm{m}$ Nadir Looking & $5: 2.145-2.185 \mu \mathrm{m}$ & $1: 8.475-8.925 \mu \mathrm{m}$ \\
& 3N: $0.76-0.86 \mu \mathrm{m}$ Nadir looking & $6: 2.185-2.225 \mu \mathrm{m}$ & $12: 8.925-9.275 \mu \mathrm{m}$ \\
& 3B: $0.76-0.86 \mu \mathrm{m}$ Backward looking & $7: 2.235-2.285 \mu \mathrm{m}$ & $13: 10.25-10.95 \mu \mathrm{m}$ \\
& & $8: 2.295-2.365 \mu \mathrm{m}$ & $14: 10.95-11.65 \mu \mathrm{m}$ \\
\hline & $15 \mathrm{~m}$ & $9: 2.360-2.430 \mu \mathrm{m}$ & \\
Ground resolution & 62 & $30 \mathrm{~m}$ & $90 \mathrm{~m}$ \\
Data rate (Mbits/s) & 23 & 4.3 \\
Cross track point pointing (o) & \pm 24 & \pm 8.55 & \pm 8.25 \\
Cross track Pointing $(\mathrm{km})$ & \pm 318 & \pm 116 & \pm 116 \\
Swath width (km) & 60 & 60 & 60 \\
Detector type & $\mathrm{S}$ & $\mathrm{PtSi}-\mathrm{Si}$ & $\mathrm{HgCdTe}$ \\
Quantization (bits) & 8 & 8 & 12 \\
\hline
\end{tabular}

Tabel 4. Unit conversion coefficients (UCC), [15].

\begin{tabular}{|c|c|c|c|c|c|}
\hline Band & $\begin{array}{l}\text { Bandpass } \\
\qquad(\mu \mathrm{m})\end{array}$ & $\begin{array}{c}\text { Effective } \\
\text { Wavelength } \\
(\mu \mathrm{m})\end{array}$ & $\begin{array}{c}\mathrm{UCC} \\
\left(\mathrm{Wm}^{-2} \mathbf{s r}^{-1} \mu \mathrm{m}^{-}\right. \\
1)\end{array}$ & $\begin{array}{c}K 1 \\
\left(\mathbf{W m}^{-2} \boldsymbol{\mu m}^{-1}\right)\end{array}$ & $\mathbf{K} 2\left({ }^{\circ} \mathbf{K}\right)$ \\
\hline 10 & $8.125-8.475$ & 8.291 & 0.0006882 & 3040.136402 & 1735.337945 \\
\hline 11 & $8.475-8.825$ & 8.634 & 0.0006780 & 2482.375199 & 1666.398761 \\
\hline 12 & $8.925-9.275$ & 9.075 & 0.0006590 & 1935.060183 & 1585.420044 \\
\hline 13 & $10.25-10.95$ & 10.657 & 0.0005693 & 866.468575 & 1350.069147 \\
\hline 14 & $10.95-11.65$ & 11.318 & 0.0005225 & 641.326517 & 1271.221673 \\
\hline
\end{tabular}


Tabel 5. Statistik NDVI

\begin{tabular}{ccccc}
\hline Rasio Saluran & Min & Mak & Rata-Rata & Stdev \\
\hline$(3-2) /(3+2)$ & 0.048276 & 0.153917 & 00.106955 & 00.015445 \\
\hline
\end{tabular}

Tabel 6. Ordinat data lapangan (manifestasi panasbumi), [5].

\begin{tabular}{|c|c|c|c|c|}
\hline \multirow{2}{*}{ No } & \multirow{2}{*}{ Manifestasi } & \multicolumn{2}{|c|}{ Ordinat } & \multirow{2}{*}{$\mathrm{T}^{\circ} \mathrm{C}$} \\
\hline & & $\mathbf{x}$ & $\mathbf{y}$ & \\
\hline 1 & Mata air panas Ajoi & 284354 & 9906084 & 46.8 \\
\hline 2 & Mata air panas Necopon & 284949 & 9906082 & 45.5 \\
\hline
\end{tabular}

Lampiran 1. Peta Terpadu, Zonasi Kemungkinan Dijumpainya Manifestasi Panasbumi Baru

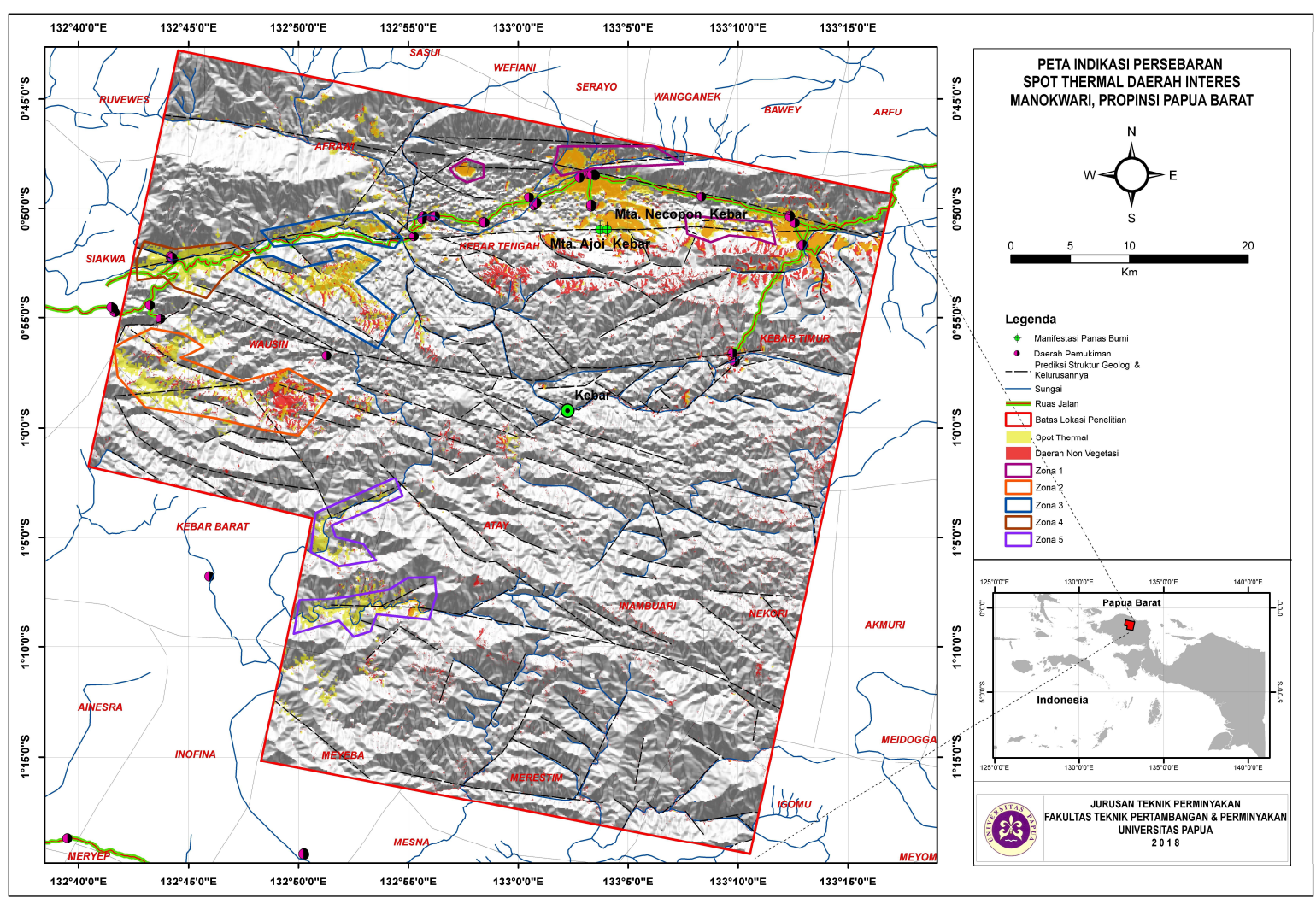

